\title{
Seija Haapakoski
}

University of Tampere

This paper analyses the translation of irony in children's literature. For children and adolescents irony is not only a matter of comprehension but also a matter of learning. However, to enjoy the literary device of irony one first has to get the point, one first has to understand the irony. Additions are discussed in this paper as a part of target text reader-oriented translation strategies. In the studied context, these strategies are regarded as tools to improve the interpretation and comprehension of irony by young target readers. Additions are discussed not merely as irony-building textual elements but also as parts of larger textual units. In the latter case, additions can provide extra information and this improves the ironic interpretation in its entirety. The results in this paper are based on a comparison of six translations (English, Finnish and Swedish as target languages) and the two source texts in German.

\section{Introduction}

Irony is a matter of interpretation and understanding. Hutcheon (1994, p. 137) maintains that irony arises through a reader's interpretation. The reader's role is therefore crucial; he or she makes irony happen. But one cannot make irony happen if the reader does not understand the irony. This is because the finesse of this literary device cannot be fully appreciated unless the reader comprehends the main point. For children and adolescents, irony is also a matter of learning. As Lypp (1986, p. 452) emphatically points out, irony is not only a matter of comprehension but first and foremost it is a matter of learning. Winner (1988, pp. 139-141) has likewise shown that the critical point for children in the process of understanding irony is above all the recognition of irony. In the following sections, I will discuss additions as a translation strategy that can increase the opportunities for young target readers to detect, interpret and understand irony. Translators as experts in both cultures can, with the right textual choices, strengthen the irony recognition process of the target readers and familiarize them with this literary device.

Irony is often seen as a kind of opposition or incongruity between the said and the unsaid and between the expressed meaning and the intended meaning (e.g., Abrams \& Harpham, 2009, p. 165). The data that have been investigated also included cases where the irony was close to Hutcheon's (1994) definition: "The said and the unsaid come together in a certain way in order to become irony" (p. 136). According to this definition, the implicit meaning does not supersede the literal one. On the contrary, the said and 
the unsaid coexist. This means that the ironic meaning is not simply equal to the unsaid meaning or some sort of opposite to what is said (Hutcheon, 1994, pp. 12-13). Hutcheon (1994, p. 56-58) further describes ironic meaning using three semantic characteristics: "irony is inclusive, differential and relational." Here the concept "inclusive" includes the idea of bringing together the said and the unsaid in such a way that they lead to the creation of something new. On the other hand "differential" refers to the critical edge of judgement, which is an essential part of the ironic message. The concept "relational" is, from the standpoint of translation studies, the most interesting. According to Hutcheon (1994), the relational strategy means that "irony operates not only between meanings (said and unsaid) but also between people (the ironist, interpreters and targets)" (p. 56). The process of translating irony further complicates this system of relations by including the translator in two different roles: first as the source-text interpreter of irony and second as the target-text "ironist".

The perspective adopted in this paper is that irony is close to humour. Indeed, humour has been regarded as one of functions of irony (e.g., Barbe, 1995, p. 28). Nevertheless, it is important to note that not all irony is humorous. Another point that needs to be made is that when studying ironic texts, it is often impossible to differentiate between irony and sarcasm. For this reason sarcasm and mockery are included in the present data.

The data for this analysis consist of two books (Ein Mann für Mama, 1972, and Luki-Live, 1978), written by the honoured Austrian author Christine Nöstlinger, and their translations into English (Anglo-American version), ${ }^{1}$ Finnish and Swedish. Nöstlinger is known for her humour which varies from slapstick to irony and sarcasm. The interplay of humorous and ironic elements in her books has also been discussed in academic studies. For example, Dilewsky (1995, p. 194) has analysed her humorous language and style which allows writing about serious issues from an ironic distance. Wild (2006, pp. 146-147, p. 239) writes of the ironic or even satirical attitude of this author towards certain issues (such as school and traditional upbringing) and how this is expressed in her texts. Nöstlinger uses irony from a self-ironic angle as well. She assumes an ironic distance to, for example, social issues or ideologies that she stands up for, such as permissive upbringing or feminism. Marx (2003, p. 282) claims that the irony used by Nöstlinger is transparent only to a few connoisseurs who do not lack wit. Translating irony in her books therefore poses a challenge for translators.

Translators have risen to this challenge by using different translation strategies. Compared with the Anglo-American translations, both the Swedish and Finnish translations tend to follow the source text model in their translations more closely. This has not always been the best strategy to communicate irony to the target readers. In passages including cultural elements (e.g., irony based on proverbs or on culture-bound similes), 
translators used compensations to transfer the core elements of irony to the target culture. Additions were thus not the only or the most common strategy but for the purpose of the present study the most interesting one.

I will begin with a short overview of the questions concerning the comprehension of irony. After that, I will move on to my case study and discuss additions as a translation strategy to support the target-text readers' interpretation and understanding of irony.

\section{The comprehension of irony by young readers}

The three most discussed issues in the studies concerning irony in children's literature are the ability of the target group to understand it, the ethical problems associated with the question of the victim in ironical texts and the cultural norms. I will focus on the questions of irony comprehension and cultural norms associated with it.

According to Kümmerling-Meibauer (1999, p. 157), what is crucial to the comprehension of irony is metalinguistic awareness. This term is defined in her article as "the ability to think about and reflect upon the nature and functions of language". She points out that the existence of early metalinguistic activity has been proven before the age of four to five. But the concept of irony is in comparison to other linguistic phenomena more demanding. The child has for example to understand a) that one does not always mean what one says and b) the intended meaning can be in contrast to the literal utterance. Apparent positive statements can in fact be negative (e.g. ironic criticism) and negative positive (e.g. ironic compliments). Therefore children do acquire a full understanding of irony relatively late, at approximately six to nine years old but there are individual differences. (Dews et al., 1996, pp. 3071-3072). However, not only metalinguistic skills help young readers understand literary irony. Hutcheon (1994, p. 92) notes how young people fluently use irony within their own discursive communities. Nonetheless, adolescents might still have troubles interpreting the ironical texts which are products of a different discursive community. This is because young people often lack the contextual information needed to interpret irony. This is also a matter of literary competence. Eggert and Garbe (2003, p. 23) have focused their research on literary socialisation and they argue that irony presumes a higher literary competence and is not fully acquired until children are 14 to 16 years old. O'Sullivan (2000, p. 116) astutely asks how the ongoing change in the children's world has an influence on their literary competence and its maturation. For instance, we may debate whether animated television sitcoms such as The Simpsons do indeed contribute to children's understanding of irony. Although the satirical view of this programme is directed at an adult audience, colourful characters do capture children's attention. Gradually children may also pay attention to the incongruity 
between what is said and what actually happens and later on to how the said and unsaid make irony happen. While children may not identify such instances as irony at first, they are still learning something about the mechanism of irony.

Since irony is also a matter of learning, some existing target-culture norms may limit the young readers' opportunities in becoming acquainted with it. Shavit (2006, pp. 35-36), O'Sullivan (2000, pp. 211-212) and Øster (2006, pp. 147-148) have presented examples of translations in which the target-culture norms or expectations have influenced translator's decisions of how to deal with irony. According to Shavit (2006, pp. 36-37), the norm of simplicity and simplification has an impact on all levels of children's literature. In the Hebrew version of Lewis Carroll's Alice in Wonderland, all the satirical or parodical elements were omitted because they were considered to be too sophisticated for a child audience. The omissions and cuts were made with a good conscience because the omitted passages containing satire and parody were not regarded as important parts of the plot.

The translators' image of the target audience affects their translation strategies. If we think that irony is a matter of learning we are more eager to make it easier for the young reader to understand it. ${ }^{2}$

\section{The analysis of additions}

Additions are included in pragmatic adaptations as translation strategies that are target-reader oriented. These have been discussed in the past in studies dealing with the translations of humour or of culture-bound features in general. Literary irony is a product of the source culture and aimed at the source-culture audience. When translating a literary work containing irony, the prospective audience of the irony changes. To catch the point, the new audience often needs extra information. They need this above all to compensate for the lack of knowledge shared by the readers of the source text. Translators have to ensure that the readers of the target text are given the presuppositions required for their access to the ironic message as a whole. This is connected to the implicit nature of irony. In other words, the understanding of irony requires shared background knowledge (see also Attardo, 2001, p. 111; Komissarov, 1991, p. 34; Nuolijärvi \& Tiittula, 2010, p. 14).

The additions in the analysed data contributed to the comprehension of irony by the target-text readers in three ways. First, the additions served as extra clues or irony markers and therefore improved the target-text readers' opportunities to detect irony. These additions were often irony markers of the "traditional" kind such as understatements, alliterations, typographic markers. There were also elaborate semantic choices which made the ironized discourse more obvious. Second, the additions supported 
the ironic interpretation by implying the tone of the said and speaker's attitude to the message, situation or persons involved in it. These additions were discourse particles, epistemic adverbs or other kinds of commenting expressions such as "heaven knows" or "I must say" in the AngloAmerican translations. Third, additions provided encyclopedic knowledge, or otherwise expanded on, the ironic context. The additions therefore not only focused on the textual elements that create irony but also on larger textual units that support the ironic context in its entirety. I will provide some examples of these results below and comment on them in more detail.

\subsection{Obtaining extra clues for ironic intention}

In the following extract, Sue (who is the protagonist in the book Ein Mann für Mama) and her family have decided to spend a lovely day at the beach. Sue's father is not very enthusiastic about all the things that Sue's mother is taking with them and makes a sarcastic remark, which is signalled by the exaggeration "equipment for a two-week expedition" (Nöstlinger, 1972, p. 23).

(1) Papa ist zapplig geworden, weil Mama so viele Sachen mitgeschleppt hat. Er hat gemeint, das reicht für eine vierzehntägige Expedition. (Nöstlinger, 1972, p. 23)

Pappa blev rastlös för mamma släpade med en sån massa saker. Han påstod att det räckte för en fjortondagarsexpedition. (Nöstlinger, 1972/1978, p. 23)

$=[$ Father got nervous because mother schlepped such an amount of things. He argued it would be enough for a two-week expedition]

The Swedish translation follows the source-text model and uses only the exaggerating phrase as an irony marker.

Isä vähän hermostui, kun äiti halusi raahata mukana niin paljon tavaraa. Hän sanoi, että sellainen määrä riittäisi vaikka kaksiviikkoiselle tutkimusmatkalle. (Nöstlinger, 1972/1994, p. 21)

$=[$ Father got a bit nervous, when mother wanted to schlep so much stuff with. He said such a amount would be enough even for a twoweek expedition]

After breakfast we went down to the beach, and Father did get rather cross because of all the stuff Mother was taking. He said she had enough equipment there for a two-week expedition. (Nöstlinger, 1972/1978, p. 15)

The Anglo-American and Finnish translators have added irony markers; the Anglo-American translation contains the adverb "rather" and the Finnish, 
"vähän" (a bit). Because of these adverbs, Sue's statement "Father did get rather cross" is clearly an understatement. This understatement signals implicitly not only the author's ironic attitude towards the situation, but also reveals that the protagonist Sue is an unreliable narrator. We can assume that the father did not get rather cross but very angry because he was the one who had to carry all the things down to the beach. The Finnish translator has also added to the father's exaggerating phrase a focus particle, "vaikka" (even), which underlines the exaggerating style of the father. In other words, the additions made by the translators increase the ironic intensity of the given episode in the target texts.

Additions serving as extra irony markers can be words or fixed phrases which have the potential to evoke ironic interpretations. In the following example the narrator echoes some selling phrases that are commonly used by the protagonist's aunt. This is done in such an exaggerating way that it reveals the author's ironic attitude towards commercials and consumption in general.

(2) Er ist überzeugt davon, dass ein geblümtes Butterfass genau der richtige Schirmständer für seine Diele ist. Er versteht auch nicht mehr, wie er so lange ohne Elefantenfu $\beta$ ausgekommen ist. Und er sieht ein, dass jeder vernünftige Mensch am bequemsten auf einem Melkschemel sitzt und dass jeder Mann von Welt eine Meerschaumpfeife über dem Bett hängen hat. (Nöstlinger, 1972, p. 15)

She could convince him a flowered butter churn was just what he needed for an umbrella stand; he couldn't imagine how he had ever got along without an elephant's foot, and of course he realized that a milking stool is a particularly comfortable form of seating, and every man of the world requires an elaborately carved meerschaum pipe hanging over his bed. (Nöstlinger, 1972/1978, p. 9)

The additions made by the Anglo-American translator (e.g., particularly, elaborately carved and comfortable form of seating) make the target reader aware of the parodied discourse because they imitate the expressions used in advertisements.

\subsection{Revealing ironic tone}

We often use discourse particles in spoken language to express our attitudes and emotions to the revealed message and the addressee. Discourse particles also have the potential to negotiate background assumptions and they also contribute to coherence (Aijmer \& Simon-Vandenbergen, 2003, p. 1123). Consequently, discourse particles can serve as irony markers too. That is why discourse particles also play a crucial role when translating 
irony in children's literature. But it is important to realize that the role of discourse particles varies from language to language (Tiittula, 1992, pp. 60-66). In the preceding paragraph of the book Luki-live, the protagonist Ariane has described the popularity of her classmate Carlo in a sarcastic manner. Later on, she ponders as to whether she was too harsh on poor Carlo. The reader of the source text has to decide on how to deal with Ariane's epistemic statement "It is possible that I describe Carlo Böhm's popularity wrong". In other words, the reader has to decide whether this statement should be interpreted as being sincere or whether there are other possibilities to interpret Ariane's statement.

(3) (Es kann sein, dass ich die Beliebtheit vom Carlo Böhm falsch beschreibe. Und das wiederum könnte damit zusammenhängen, dass ich einen Teil der Wut, die ich auf seine Schwester habe, auf den armen Carlo übertrage. Warum ich so eine Wut auf seine Schwester habe, werde ich etwas später erklären.) (Nöstlinger, 1978, p. 91)

(Oh, dear. Perhaps I'm all wrong about Carlo's popularity, and then again, that [emphasis by translator] could be because I'm taking out some of the way I feel about Carlo's sister on poor Carlo himself. You'll soon find out how I feel about his sister.) (Nöstlinger, 1978/1979, p. 71)

In the Anglo-American translation, the Ariane's self-ironic tone is more overt to the reader. The translator boosts Ariane's self-irony by adding the interjection "Oh dear". ${ }^{4}$ Ariane's next statement is therefore easier to interpret as being self-ironic or even sarcastic. The epistemic adverb "perhaps" and pronoun "all" create an exaggerated tone and function as irony markers. Meanwhile, the Swedish and Finnish translators have translated Ariane's statement by closely following the source text's model. The only clue therefore with regard to the irony is the epistemic tone of Ariane's first statement, which is not equally effortless to interpret as being ironic.

The translators also added irony markers in the passages where the context reveals the speaker's opposite meaning. Ariane's comment that "my mother was very annoyed" prepares readers for the mother's sarcastic question. The sentence following the question leaves no doubt about the mother's attitude. As Pelsmaekers and Van Besien (2002) point out: "Irony arises when there is some kind of contrast or incongruity between what is said (the propositional content) and what can be inferred from the situation" (p. 243).

(4) Am dritten Tag meiner Krankheit ist er mit einem Leihwagen nach Hause gekommen und da war meine Mama sehr empört. $\Perp$ Darf ich zur Gehaltserhöhung gratulieren? «, hat sie mit einer Stimme gefragt, 
mit der man Konservenbüchsen hätte aufschneiden können. (Nöstlinger, 1978, p. 142)

Tredje dagen jag var sjuk kom han hem i hyrbil, och då blev min mamma väldigt indignerad. "Får man kanske gratulera till en löneförhöjning?" frågade hon med en röst som man hade kunnat bryta upp konservburkar med. (Nöstlinger, 1978/1979, p. 107)

$=[$ The third day I was sick, he came home in a rented car and then my mother got very annoyed. "May I possibly congratulate you on getting a raise?" she asked in a voice that you could have used to open a tin can.]

The third day I was sick, he came home in a rented car. My mother was very annoyed. "Oh, can I congratulate you on getting a raise?" she asked in a voice that you could have used to open a tin can. (Nöstlinger, 1978/1979, p. 104)

The Swedish translator added an epistemic adverb "kanske" (possibly) as an irony marker to the mother's question. By contrast, the Anglo-American translator used the discourse particle "oh" for the same purpose. They both underlined the sarcastic tone of the mother's question. Consequently, the mother's mocking intention becomes more obvious. The Finnish translation of the same episode shows how every word counts when it comes to interpreting irony and sarcasm:

Sairauteni kolmantena päivänä isä tuli kotiin vuokratulla autolla, ja silloin oli äitini kovin hämmästynyt »Saanko onnitella palkankorotuksen johdosta?» hän kysyi äänellä, jolla olisi voinut leikata auki säilykepurkin.(Nöstlinger, 1978/1982, p. 141)

$=[$ The third day I was sick father came home in a rented car and my mother was really astonished. "Can I congratulate you on getting a raise?" she asked in a voice that you could have used to open a tin can.]

By misunderstanding the German word "empört" and using the word "astonished" instead of "annoyed", the translator makes the mother's question sound sincere. Ariane's reaction to her mother's chilly tone changes the text resulting in something which is incoherent. As a result, the target reader is undoubtedly confused.

(5) Der Papa fährt zum Haus der Großmutter. Eigentlich müssten sich Su und I besonders innig von ihm verabschieden. Sie sehen ihn ja vor ihrer Reise nicht mehr. I fällt nichts Inniges ein. Sie sagt: »Fröhliche Weihnachten, Herr Papa! Und denk immer daran: Du hast deine Töchter unheimlich glücklich gemacht. Besser, als wir es haben, könnt es gar nicht sein. Danke schön!« I ergreift sämtliche Weihnachtspäckchen, steigt aus dem Auto und knallt die Tür zu. Su 
bleibt sitzen. Sie flüstert: »Du, Papa, I meint es nicht so arg! « (Nöstlinger, 1972, p. 126)

Father drove to Grandmother's house. Sue and J should have said goodbye to him particularly nicely, since they wouldn't be seeing him again before Christmas. Obviously nothing nice occurred to J. She said sarcastically "Happy Christmas, Father dear. Oh, think how happy you've made your daughters. Oh, isn't everything just lovely! Thanks so [emphasis by translator] much!” She seized all the parcels, got out of the car and slammed the door. Sue stayed put. She whispered, "Father, $J$ doesn't really mean it!" (Nöstlinger, 1972/1978, p. 92)

In example 5 the addition used first is of a slightly different nature. The translator gives clear advice on how to interpret J.'s statement. She adds the sentence "She said sarcastically". She does not seem to rely on the reader's ability to interpret the irony markers rightly (for example, the utterance "Thanks so much" is often interpreted as being sarcastic, and in translation, the italics are further used for the word "so" to underline the tone).

\subsection{Stylistic choices to increase ironic effect}

Even stylistic choices can be used to increase an ironic or sarcastic effect. The Finnish translator in particular used alliteration as an irony marker in her target text to make the sarcastic tone of the teenage protagonist more obvious.

(6) Und dann sucht er eine ganz raffinierte Abkürzung zur Autobahn zurück. (Nöstlinger 1978, p. 13)

Sitten hän etsii oikein ovelan oikotien takaisin moottoritielle. (Nöstlinger, 1978/1982, p. 13)

$=$ [After that he searches for a super subtle shortcut back to highway.]

The Finnish translator succeeds in combining alliteration and the semantic value of the chosen words so that they have the potential to increase the sarcastic effect in the target text. The shortcut back to highway that was chosen is everything else but short or clever. The use of alliteration in the Finnish target texts continues to be in the style of the Finnish national epic, the Kalevala.

The Anglo-American translator was the only one to use typographic markers such as italics to underline the potential ironic instances in her translations. In the following example, the protagonist Sue echoes what was said and heard during her parent's quarrel. Later on, she makes her own remarks by negating the original statements. Irony in this example comes close to Giora's (1995) type of irony as a mode of indirect negation. Giora 
points out that "irony understanding involves processing both the negated and implicated messages, so that the difference between them may be computed" (p. 239).

(7) Und Papa bekommt auch nur ganz selten Glupschaugen, wenn ein blondes Fräulein vorbeigeht. (Nöstlinger, 1972, p. 20)

And Father doesn't goggle at pretty blonds every [emphasis by translator] time he sees one. (Nöstlinger, 1972/1978, p. 13)

Italics used for the word "every" makes irony more visible. It's obvious that Sue's father still ogles at pretty blonds quite often.

\subsection{Explicating ironic context}

By explicating an ironic context, I refer to the additions with which translators made sure that the readers of the target text were provided with the necessary background information.

(8) Und da war es leichter, ohne Visum und Pass in die CSSR einzureisen, als über die Mittelganggrenze zu den Buben zu kommen. (Nöstlinger, 1978, p. 10)

You could have gotten from Austria (where we live) into Czechoslovakia without a passport more easily than you could have crossed that aisle to the row of boys' desks. (Nöstlinger, 1978/1979, p. 10)

The target-text translator has added the name of the protagonist's mother country and, in parentheses, her comment on living in that country. As a result, the target-text reader gets the idea of the neighbouring countries. In order to understand the irony of the situation as whole, one still has to be familiar with the European political history after the Second World War. For example, one needs to understand the frames that can be evoked by the use of abbreviation CSSR. So processing and interpreting irony is often influenced by frames which are activated by conscious textual choices. The translator has to ponder what kind of frames and thereby associations are activated in the source text and how they are transferred to the target text. Seemingly minor semantic choices have effects on the ironic frames. In the following example the teacher's surname is a central part of a satirical play.

(9) Der Parasol stand an der Klassentür und schaute empört nach uns aus. (Der Parasol heißt: Dr. Monika Pilz und ist unsere Klassenlehrerin (...) (Nöstlinger, 1978, p. 23) 
In this section the translators have settled on different translation strategies. The Swedish translator has used the translator's footnote to explain the meaning of a German surname, which makes up the main substance of a satirical wordplay.

Tofsskivlingen stod i klassrumsdörren och höll indignerad utkik efter oss. (Tofsskivlingen heter Monika Pilz* och är vår klassföreståndare.(...)

* Det tyska ordet "Pilz" betyder svamp. (Nöstlinger, 1978/1979, p. 19)

$=[$ The Toadstool was standing at the class room door and looks out indignant for us. Toadstool's name is Monika Pilz* and she is our home room teacher

* The German word "Pilz" means mushroom]

As for the Anglo-American translation, the protagonist Ariane/Angela turns to the reader and explains the origin of the nickname pupils have given to their teacher.

The Toadstool was standing at our homeroom door, waiting for us, and she looked cross. Her name is really Dr. Monica Pilz, and Pilz is the German word for a mushroom sort of fungus, so we call her the Toadstool. (Nöstlinger, 1978/1979, p. 21)

The Finnish translator has utilized the possibilities of the Finnish language. First, she has replaced the German surname with a Finnish one. She has chosen a Finnish name of a mushroom (boletus) and added a common ending used for Finnish surnames, the suffix "-nen". The same suffix can also be used to form diminutives. Thus, the translation of the teacher's name has a pejorative meaning and, moreover, the nickname evokes connotations of a bitter person. Together they increase the satirical edge of the episode. In modern Finland, the use of titles is not as common as in Germany or in Austria. By adapting the translation to the Austrian model, the Finnish translator actually enhances the ironic tone.

Sappitatti seisoi luokan ovella ja katseli kiihtyneenä ulos meihin päin. (Sappitatti tarkoittaa maisteri Monika Tattista, joka on luokanvalvojamme (...) (Nöstlinger 1978/1982, p. 23)

$=[$ Bitter Boletus was standing at the class room door and watching us overheated. (Bitter Boletus means Master of Arts Monika Boletus who is our home room teacher)]

The translator can also add some sort of explanation to make the situational context more explicit. In the following passage, Ariane makes a sarcastic remark about her parents and their behaviour. She mentions in parentheses something about a clever policeman. 
(10) Auf die Idee, einmal in mein Zimmer und mein Bett zu lugen, kamen die drei Wahnsinnigen nicht! (Vielleicht hätte ihnen das ein kluger Polizist auf der Wachstube empfohlen.) (Nöstlinger, 1978, p. 139)

What is left implicit in the source text is normal behaviour by parents when their child is missing: they call the police. But in the Anglo-American translation, this pattern is not taken as being self-evident.

Bless their silly hearts, the three of them never thought of looking in my bedroom. (If they'd called the police, some clever policeman might have suggested that.) (Nöstlinger, 1978/1979, p. 101)

By adding an explanatory sentence "If they'd called the police", the target text readers are helped in creating the required frame. Otherwise they might wonder how the clever policeman had suddenly appeared in the text. Both the Swedish and Finnish target texts are literal translations of the source text. They also seem to rely more on the readers' general knowledge.

The translators also added some suitable adverbs to tightly bind what was said to the surrounding context and thereby to ensure the ironic interpretation.

(11) »Hast du schon immer so gut rechnen können? «, fragt $\mathrm{Su}$ heuchlerisch. (Nöstlinger, 1972, p. 102)

- Har du alltid kunnat räkna så här bra? frågar Su hycklande. (Nöstlinger, 1972/1978, p. 104)

$=[$ Have you always been this good at maths? asks Sue two-facedly]

The Swedish translator has added the adverb "här", pointing to the previous course of events in the book, which clearly shows Sue's great aunt Alice is actually hopeless at maths. The same idea is expressed implicitly in the source text. Sue's question is therefore not sincere at all. On the contrary, she is being sarcastic. This episode that ridicules adults is missing from the Anglo-American translation.

\section{Conclusions}

Irony is a matter of interpretation and understanding. More specifically, literary irony comes into being as a product of source culture and is aimed at source-culture audience members. When translating a literary work containing irony, the prospective audience changes. To comprehend the point a new audience often needs extra information. Since irony is implicit by nature, understanding it requires shared background knowledge. Therefore, additions have been discussed extensively because by using them, the lack of knowledge can be compensated for by the readers of the 
target text. Additions as target reader-oriented translation strategies have been previously discussed in studies dealing with translations of humour or culture-bound features in general. These strategies have also been studied as parts of translation universals, which indicates that translations tend to be more explicit than source texts.

The results of this study indicate that additions as a pragmatic strategy can improve the opportunities of young readers to interpret and understand irony. The first additions increased the number of irony markers in the analysed text passages and their ironic intensity. Compared with the source text, irony in the target text often becomes more visible or overt and thus easier to detect. The second point is the additions supported the ironic interpretation by implying the tone of the said and the speaker's attitude to the message, situation or to the people involved in it. The final point is additions gave the target text readers the extra information needed for processing an ironic instance. This pragmatic strategy is thus associated with the author's (and in this case also the translator's) responsibility to guarantee the comprehension of irony and avoid misunderstandings (see also Hutcheon 1994, p. 120). It is also part of the author's ethical responsibility. As Cadden (2000, p. 153) points out, the author has to build the ironical text in a way that the young readers have opportunity to detect and cope with the irony.

If we take a closer look at the translations analysed, additions were used in all six translations. However there were differences in the quantity of additions. As representatives of cultures in which translated literature has a central position within the literary system, both the Swedish and Finnish translations tend to follow the source text model in their translations. As a result, especially the Swedish translations had fewer additions. The AngloAmerican translator's approach was freer and she emphasized the humorous side of the books more. Here, the additions were, for example, used to underline the self-ironic and sarcastic tone of the young protagonist in the book entitled Luke and Angela. Some of the additions in this book were the result of omissions and cuts made in the previous chapters. The additions provided the needed background information for example, "from Austria (where we live)") for the target text reader. Some differences also emerged in the irony markers between the source texts and the target texts. For instance, both the Anglo-American and the Finnish translators used understatement as an irony marker, which was not the case in the source texts. The Finnish translator also favoured alliteration and used Finnish suffixes to increase ironic intensity. In the Anglo-American translations, typographic markers were another means used to underline the potential ironic instances. In all translations, the additions might have compensated for the less successful translation choices in some of the ironic passages.

In further studies based on translators' interviews, it might be possible determine to what extent these additions are based on conscious 
choices and what role the translator's image on target audience plays in the translations of irony.

\section{References}

\section{Primary sources}

Nöstlinger, C. (1972). Ein Mann für Mama. Hamburg: Oetinger.

Nöstlinger, C. (1978). Luki-live. Hamburg: Oetinger.

Nöstlinger, C. (1978). En man för mamma. C. Tranmark-Kossmann. (Translated into Swedish. German original Ein Mann für Mama, 1972). Stockholm: Berghs.

Nöstlinger, C. (1979). Lyckliga Lucke. K. Nyman. (Translated into Swedish. German original Luki-live, 1978). Stockholm: Raben \& Sjögren.

Nöstlinger, C. (1979). Luke and Angela. A. Bell. (Translated into English. German original Luki-live, 1978). San Diego: Harcourt Brace Jovanovich.

Nöstlinger, C. (1978). Marrying off mother. A. Bell. (Translated into English. German original Ein Mann für Mama, 1972). San Diego: Harcourt Brace Jovanovich.

Nöstlinger, C. (1982). Luki-live. L. Viljakainen. (Translated into Finnish. German original Luki-live, 1978). Helsinki: Otava.

Nöstlinger, C. (1994). Vanhemmista on paljon vaivaa. L. Viljakainen. Translated into Finnish. German original Ein Mann für Mama, 1972). Helsinki: Otava.

\section{Secondary sources}

Abrams, M. H., \& Harpham G. G. (2009). A glossary of literary terms (9th ed.) .Boston, MA: Wadsworth Cengage Learning.

Aijmer, K., \& Simon-Vandenbergen, A.-M. (2003). The discourse particle "well" and its equivalents in Swedish and Dutch. Linguistics, 41(6), 1123-1161.

Attardo, S. (2001). Humorous texts: A semantic and pragmatic analysis. Berlin: Mouton de Gruyter.

Barbe, K. (1995). Irony in context. Amsterdam: John Benjamins.

Cadden, M. (2000). The irony of narration in the young adult novel. Children's Literature Association Quarterly, 25(3), 146-154.

Dews, S.,Winner, E., Kaplan, J., Rosenblatt, E., Hunt, M., Lim, K. ... Smars, B. (1996). Children's understanding of the meaning and functions of verbal irony. Child Development, 67, 3071-3085.

Dilewsky, K. J. (1995). Christine Nöstlinger als Kinder- und Jugendbuchautorin: Genres, Stoffe, Sozialcharaktere, Intentionen (2nd ed.). Frankfurt: Haag und Herchen.

Eggert, H., \& Garbe C. (2003). Literarische Sozialisation (2nd ed.). Stuttgart: Haag und Herchen.

Giora, R. (1995). On irony and negation. Discourse Processes, 19, 239-264. 
Hutcheon, L. (1994). Irony's edge: The theory and politics of irony. London: Routledge.

Hutchby, I. (2001). "Oh”, irony and sequential ambiguity in arguments. Discourse and Society, 12(12), 123-141.

Komissarov, V. N. (1991). Language and culture in translation: Competitors or collaborators. TTR: Traduction, Terminologie, Rédaction, 4(1), 33-47.

Kümmerling-Meibauer, B. (1999). Metalinguistic awareness and the child's developing concept of irony: The relationship between pictures and text in ironic picture books. The Lion and Unicorn, 23(2), 157-183.

Lypp, M. (1986). Lachen beim Lesen: Zum Komischen in der Kinderliteratur. Wirkendes Wort, 36(6), 439-455.

Marx, S. (2003). Christine Nöstlinger in Italien: Ein Beitrag zur Rezeption und Übersetzung ihres Frühwerks. In S. Fuchs \& E. Seibert (Eds.), ... weil die Kinder nicht ernst genommen werden: Zum Werk von Christine Nöstlinger (pp.275-294). Wien: Edition Praesens.

Nuolijärvi, P., \& Tiittula, L. (2010). Irony in political television debates. Journal of Pragmatics, doi:10:1016/j.pragma.2010.01.019.

O’Sullivan, E. (2000). Kinderliterarische Komparatistik. Heidelberg: Winter.

Pelsmaekers, K., \& Van Besien, F. (2002) Subtitling irony: Blackadder in Dutch. The Translator, 8(2), 241-266.

Rahtu, T. (2006). Sekä että: Ironia koherenssina ja inkoherenssina. Helsinki: SKS.

Shavit, Z. (2006). Translation of children's literature. In G. Lathey (Ed.), The translation of children's literature: A reader (pp. 25-40). Clevedon: Multilingual Matters.

Shavit, Z. (1986). Poetics of children's literature. Athens, GA: The University of Georgia Press.

Tiittula, L. (1992). Puhuva kieli. Helsinki: Finn Lectura.

Wild, I. (2006). Rollenmuster - Rollenspiele: Literarische Erkundungen von Pubertät und Adoleszenz. Gesammelte Aufsätze zur neueren Jugendliteratur. Frankfurt: Peter Lang.

Winner, E. (1988). The point of words: Children's understanding of metaphor and irony (2nd ed.). Cambridge, MA: Harvard University Press.

Øster, A. (2006). Hans Christian Andersen's fairy tales in translation. In J. Van Coillien \& W. P. Verschueren (Eds.), Children's literature in translation: Challenges and strategies (pp.141-155). Manchester: St. Jerome.

1 I have used copies published by Publishing House Harcourt Brace Jovanovich in to the US market. Both books were first published in Great Britain by Andersen Press Ltd. Therefore I use the term « Anglo-American ».

2 We must bear in mind that translators are not the only decision-makers. Not all decisions concerning irony in translated texts are made by translators. Editors too have their own views. 
This was the case in the Anglo-American translations (Bell, personal communication, 5 May 2009).

3 All the emphases (underscores) in the examples are mine, except where stated otherwise.

4 Hutchby (2001) has pointed out that the marker «oh» is often followed by ironic propositions.

5 According to Rahtu (2006, p. 55), epistemic adverbs are also used to signal that an ironic interpretation is possible in a given context. 